\title{
Quality of life of patients with rheumatoid arthritis under biological therapy
}

\author{
Amanda Figueiredo Barbosa Azevedo ${ }^{1}$, Katia Cristina Lima de Petribứ2, Moacir de Novaes Lima³, André Santos da Silva4*, \\ José de Arimatea Rocha Filho ${ }^{5}$, Maria Helena Queiroz de Araújo Mariano ${ }^{6}$, Eliézer Rushansky ${ }^{7}$

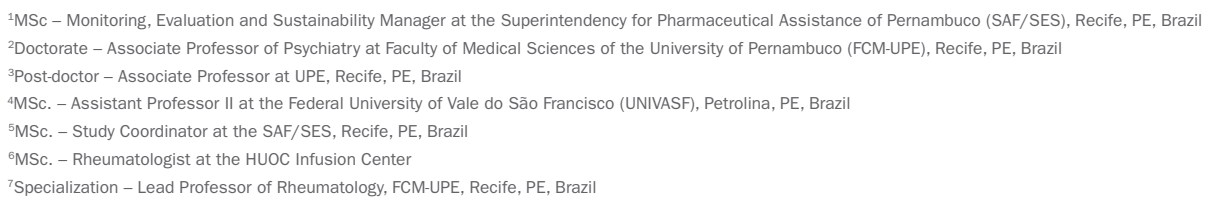

Study conducted at the University of Pernambuco (UPE), Recife, PE, Brazil

Article received: $7 / 23 / 2014$ Accepted for publication: 8/6/2014 *Correspondence: Address: Av. José Sá Maniçoba, s/n Centro, Petrolina, PE - Brazil Postal Code: $56.304-917$ Phone: (87) 2101-6862 andre.santoss@univasf.edu.br

\section{SUMmARY}

Objective: assessing health-related quality of life (HRQL) in patients with rheumatoid arthritis (RA), before and after treatment with biological therapy.

Methods: a longitudinal study, conducted from November 2010 to September 2011, with implementation of the instruments HAQ II (health assessment questionnaire) and SF-36 (medical outcomes short-from health survey). Barlett test, Anova, Friedman and paired t-test were performed for multiple extracts.

Results: 30 patients were evaluated, mean age of 47.6 (SD: 12.25) years and prevalence of females (90\%). The mean score of HAQ II before treatment was 1.97, with significant reduction of up to 1.23 after six months of biological therapy $(\mathrm{p}<0.01)$. Most of the SF-36 domains showed significant improvement after six months of treatment ( $\mathrm{p}<0.01)$, highlighting the social aspects, pain, physical functioning, emotional issues, vitality and physical aspects.

Conclusion: the use of biologic therapy in patients with RA refractory to standard therapies proved to be an important pharmacological strategy for improving HRQL.

Keywords: rheumatoid arthritis, biological therapy, quality of life, rheumatology, rheumatic diseases.

\section{INTRODUCTION}

Rheumatoid arthritis (RA) is an autoimmune, systemic and chronic disease, characterized by inflammation of the synovial membranes that can lead to osteoarticular destruction. ${ }^{1}$ There is an estimated prevalence in the world population from 0.5 to $1 \%$, with annual incidence of 0.02 to $0.05 \%$. Predominance is two to three times higher in females, whose peak is observed around age 50 years. ${ }^{2} \mathrm{~A}$ study by Senna et al. ${ }^{3}$ estimated the RA prevalence in the Brazilian population at $0.46 \%$. The use of biological agents for treating this disease is a challenge, leading to the possibility of reducing the consequences of the disease.

Quality of life (QL) is a concept increasingly used in the assessment of health conditions of a given population (diet habits, housing, employment, recreation, etc.) and of the impact of therapeutic applications associated with different groups of diseases. ${ }^{4}$ The QL self-report is a multidimensional concept comprising physical, social and emotional components associated with illness, thus poiting out how difficult it is to define QL. ${ }^{4}$

The QL self-report can be obtained in a systematic way by means of semi-structured interviews, qualitative assessments and questionnaires, the latter being the main route used by most of the published scientific literature for having a more affordable cost, immediate results and easier data analysis. ${ }^{5}$

Health-related quality of life (HRQL) refers to the impact of disease and treatment on the individual's welfare. Patients diagnosed with RA have significant decreases in HRQL, resulting from pain, impaired physical function and fatigue. ${ }^{6}$ Generic measures, such as the SF-36 questionnaire, have been frequently used in clinical trials of RA to assess HRQL.? 
Given the scarcity of studies on QL in patients with RA, the aim of this study is to evaluate HRQL in Brazilian patients with RA before and after biological therapy.

\section{Methods}

\section{Design and study site}

A longitudinal and prospective before and after study was conducted on a sample of 30 RA patients refractory to conventional pharmacological treatments. Data were collected from November 2010 to September 2011.

The study site was the Infusion Centers at the Oswaldo Cruz University Hospital (HUOC) and Clinics Hospital (HC) UFPE, as well as the High Complexity Pharmacy of Pernambuco, Metropolitan Unit, located in the district of Boa Vista, city of Recife, Pernambuco, Brazil.

\section{Patient selection}

The criteria used to include patients in the study were the following:

1. having RA diagnosed by medical expert from the HUOC and/or HC, meeting the classification criteria defined by the American College of Rheumatology (ACR), ${ }^{8}$ as well as the inclusion criteria defined by the Clinical Protocol and Therapeutic Guidelines of the Ministry of Health of Brazil for pharmacological treatment with biological therapy;

2. being an adult patient of either gender, and residing in the state of Pernambuco;

3. being a patient with RA refractory to conventional immunosuppressive therapy;

4. not having previously started treatment with a biological therapy;

5. being registered and authorized by specialized component of pharmaceutical care to initiate the biological therapy with anti-TNF (40mg Adalimimabe, $50 \mathrm{mg}$ Etanercept and 100mg Infliximab);

6. consenting to participate in research by signing an informed consent form (INF).

Patient exclusion criteria were the opposite of any or all of the inclusion criteria.

\section{Instruments for data collection}

After being selected, before starting the biological therapy, patients were evaluated by applying the following QL questionnaires: SF-36, HAQ II and the socioeconomic questionnaire. These instruments were applied once again after three and six months of starting treatment.
Generic instrument of QL medical outcomes short-from health survey - SF-36

The domains assessed in the SF-36 were eight: functional capacity (ten items), physical aspects (four items), pain (two items), general health (five items), vitality (four items), social aspects (two items), emotional issues (three items) and mental health (five items), in addiction to one item to compare current health status and that of the previous year. ${ }^{10}$

\section{Specific instrument of QL for arthritis health assessment} questionnaire - HAQ II

This is a questionnaire that assesses five dimensions: disability, discomfort, drug side effects, cost and death. Composed of 10 questions grouped into eight categories that seek to understand the level of difficulty the patient has to perform such activities, as well as the need for assistance to perform them. ${ }^{11}$

Functional disability in early rheumatoid arthritis (RA) affects patients and their lives. The degrees of disability based on the health assessment questionnaire (HAQ) score are categorized into 4 grades: (1) HAQ: 0 (no disability); (2) HAQ: 0.1-0.99 (mild to moderate difficulty); (3) HAQ: 1-1.99 (moderate to severe disability); (4) HAQ: 2-3 (severe to very severe disability).

\section{Socioeconomic questionnaire}

This is a questionnaire prepared by the research team to define the profile of patients with RA treated with biological therapy, regarding age, gender, education level, current occupation, marital status and income.

\section{Data analysis}

Data were entered into a spreadsheet program Microsoft Office Excel 2007 for Windows, and transported to the statistical program R, being processed and analyzed. Descriptive analysis of single frequency for categorical variables (gender, education level, marital status, monthly income, current occupation) and measures of central tendency (median and mean) and variability (standard deviation) were performed for continuous variables (age, SF-36 and HAQ II quality of life questionnaires).

Bartlett's homogeneity test (all higher than 0.05), Anova and Friedman test identified the significance and relevance of parametric test and paired t-test to identify the differences between means.

After having applied the Bartlett test for homogeneity of variances, indicating normality (all $\mathrm{p}$ values obtained were higher than 0.05 ), the paired t-test for mul- 
tiple extracts was applied, assessing mean differences. The significance level was set at 0.05 .

\section{Ethical aspects}

The study was approved by the Ethics Committee in Research-HUOC (no. 90/2010 and CAAE no. 0083.0.106.000$10)$ and all patients signed an informed consent form.

\section{Results}

30 patients diagnosed with RA code M05 and M06 (ICD10) were evaluated and followed before and after starting, for the first time, the use of biological anti-TNF $\alpha$ (adalimumab, etanercept and infliximab) for six months.

Females predominated (90\%) and the mean age was 47.6 years $(25-81)$. The majority $(53.3 \%)$ had been diagnosed with RA for more than five years.

During the follow-up, adverse reaction was observed in three cases, one of them being cytomegalovirus and two cases of rash. The drug was suspended for failure to respond or not meeting the expectations proposed for treatment in both cases. Treatment was discontinued in six cases for personal reasons. During the study period there was no shortage of anti-TNF $\alpha$ biological medicines.

Health-related quality ${ }^{1}$ (Table 1) summarizes the socioeconomic, clinical and serological characteristic of the population studied.

TABLE 1 Socioeconomic, clinical and serological characteristics of patients with diagnosis of RA prior to the use of biological medication. Pernambuco, Recife, 2011.

\begin{tabular}{|c|c|c|}
\hline Characteristics & & n (\%) \\
\hline \multirow[t]{6}{*}{ Age (years) } & & $47,63( \pm 12,25)$ \\
\hline & $>20-30$ & $2(6.7 \%)$ \\
\hline & $>30-40$ & $7(23.3 \%)$ \\
\hline & $>40-50$ & $6(20.0 \%)$ \\
\hline & $>50-60$ & $13(43.3 \%)$ \\
\hline & $>60$ & $2(6.6 \%)$ \\
\hline \multicolumn{3}{|l|}{ Gender } \\
\hline & Male & $3(10.0 \%)$ \\
\hline & Female & $27(90.0 \%)$ \\
\hline \multicolumn{3}{|l|}{ Education } \\
\hline & Illiterate & $1(3.3 \%)$ \\
\hline & Basic education & $9(30.0 \%)$ \\
\hline & High school & $14(46.7 \%)$ \\
\hline & Higher education & $3(10.0 \%)$ \\
\hline & Postgraduate & $3(10.0 \%)$ \\
\hline \multicolumn{3}{|c|}{ Current occupation } \\
\hline & On medical leave & $3(10.0 \%)$ \\
\hline
\end{tabular}

TABLE 1 (Cont.) Socioeconomic, clinical and serological characteristics of patients with diagnosis of RA prior to the use of biological medication. Pernambuco, Recife, 2011.

\begin{tabular}{|c|c|c|}
\hline Characteristics & & n (\%) \\
\hline & Retired & $1(3.3 \%)$ \\
\hline & Retired for disability & $6(20.0 \%)$ \\
\hline & Housewife & $7(23.3 \%)$ \\
\hline & Working & $13(43.3 \%)$ \\
\hline \multicolumn{3}{|l|}{ Marital status } \\
\hline & Married & $12(40.0 \%)$ \\
\hline & Divorced & $2(6.7 \%)$ \\
\hline & Single & $14(46.7 \%)$ \\
\hline & Widowed & $2(6.7 \%)$ \\
\hline \multicolumn{3}{|c|}{ Household income } \\
\hline & 01 minimum wage & $6(20.0 \%)$ \\
\hline & 02-05 MW & $15(50.0 \%)$ \\
\hline & 06-10 MW & $5(16.7 \%)$ \\
\hline & More than $10 \mathrm{MW}$ & $4(13.3 \%)$ \\
\hline \multicolumn{3}{|c|}{ International classification of diseases (ICD-10) * } \\
\hline & M05 & $20(66.7 \%)$ \\
\hline & M06 & $10(33.3 \%)$ \\
\hline \multicolumn{3}{|c|}{ Duration of diagnosis } \\
\hline & 1 to 2 years & $5(16.7 \%)$ \\
\hline & 3 to 5 years & $8(26.7 \%)$ \\
\hline & 5 years or more & $16(53.3 \%)$ \\
\hline \multicolumn{3}{|c|}{ Rheumatoid factor } \\
\hline & Negative & $10(33.3 \%)$ \\
\hline & Positive & $20(66.7 \%)$ \\
\hline \multicolumn{3}{|l|}{ Physiotherapy } \\
\hline & No & 27 (90.0\%) \\
\hline & Yes & $3(10.0 \%)$ \\
\hline
\end{tabular}

* M05 (positive for RA); M06 (negative for RA)

Table 2 shows the scores for the quality of life questionnaires used in the study (SF-36 and HAQ II).

The degree of disability or incapability of patients with RA measured by the HAQ II is shown in Table 3.

Regarding the therapeutic treatment, 13 patients used adalimumab, 13 used etanercept and 4 used infliximab. Out of these users, 13 (43.3\%) were treated with anti-TNF $\alpha$ monotherapy and 17 (56.7\%) in combined use of disease-modifying agents (DMARD) with methotrexate or leflunomide.

\section{Discussion}

In this study there was a predominance of female participants (90\%); this population is three times more affected than men. ${ }^{12-16}$ Our ratio was higher than that indicat- 
TABLE 2 HAQ II and SF-36 scores of patients diagnosed with RA - Baseline evaluation, after 3 and 6 months. Pernambuco, Recife, Brazil, in 2011

\begin{tabular}{|c|c|c|c|c|c|c|}
\hline \multirow[t]{2}{*}{ Questionnaires } & \multirow[t]{2}{*}{ Baseline (I) } & \multirow[t]{2}{*}{3 months (II) } & \multirow[t]{2}{*}{6 months (III) } & \multicolumn{3}{|c|}{ Comparisons ( $\mathrm{p}$ values)* } \\
\hline & & & & | $\mathbf{x}$ || & I x III & II x III \\
\hline HAQ II & $1.97(0.66)$ & $1.21(0.73)$ & $1.23(0.74)$ & $2.2 \mathrm{e}-07$ & $3.0 \mathrm{e}-06$ & 1 \\
\hline \multicolumn{7}{|l|}{ SF-36 (domains): } \\
\hline Functional capacity & $31.33(23.74)$ & $51.33(28.74)$ & $53.67(26.81)$ & $4.3 e-05$ & $3.2 \mathrm{e}-05$ & 0.56000 \\
\hline Limitations due to physical issues & $18.33(34.70)$ & $53.33(43.42)$ & $57.50(45.08)$ & 0.00019 & $7.6 e-05$ & 0.60859 \\
\hline Pain & $31.57(24.08)$ & $55.17(29.08)$ & $52.20(29.14)$ & $2.2 \mathrm{e}-06$ & 0.00051 & 0.62834 \\
\hline Overall health & $45.97(20.63)$ & $59.20(20.53)$ & $53.80(26.04)$ & 0.00820 & 0.33680 & 0.16841 \\
\hline Social aspects & $48.75(26.13)$ & $64.17(26.00)$ & $70.83(28.30)$ & 0.00660 & 0.00014 & 0.11080 \\
\hline Vitality & $46.83(24.01)$ & $58.17(21.99)$ & $54.50(25.03)$ & 0.0615 & & 0.36132 \\
\hline Limitations due to emotional issues & $30.00(40.45)$ & $57.78(47.89)$ & $72.22(42.96)$ & 0.00626 & 0.00012 & 0.08500 \\
\hline Mental health & $52.40(22.27)$ & 64.93(23.99) & $60.53(27.41)$ & 0.00800 & 0.12800 & 0.24162 \\
\hline
\end{tabular}

Mean evaluation (standard deviation).

* Paired $t$-test for multiple extracts (evaluating mean differences) $\mathrm{p}<0.05$

TABLE 3 Degree of disability measured by the HAQ II. Pernambuco, Recife, Brazil, in 2011.

\begin{tabular}{lll} 
Questionnaire & Baseline & $\mathbf{6}$ months \\
\hline HAQ II & $\mathrm{n} \%$ & $\mathrm{n} \%$ \\
\hline Mild disability (HAQ II de 0 a 1) & $2(6.7 \%)$ & $14(46.7 \%)$ \\
\hline Moderate disability (HAQ II >1 a 2) & $15(50 \%)$ & $12(40 \%)$ \\
\hline Severe disability (HAQ II >2 a 3) & $13(43.3 \%)$ & $4(13.3 \%)$ \\
\hline
\end{tabular}

HAQ II: Health Assessment Questionnaire II.

ed in the literature (9:1), corroborating studies with Brazilian populations, ${ }^{17-19,14}$ which show that the female/ male ratios are higher than in the international literature (7.3:1 and 9:1), possibly due to the great heterogeneity of the study population, hormonal issues and the fact that, traditionally, women seek more often health services than men. ${ }^{20-22}$ Regarding age, the mean was 47.6 years, ranging from 25 to 81 years. These results are consistent with data obtained by other authors. ${ }^{14,23}$

Contrary to that observed in other studies, ${ }^{24-26}$ most patients $(46.7 \%)$ had over 10 years of formal education, which may facilitate access to information and purchase of products and services, besides contributing to better treatment compliance. Biological therapy can still be considered little known, thus people with more years of education may have greater access to this information. It is noteworthy that many patients work (43.3\%), though in occupations with less physical work.

Regarding the mean scores of the HAQ II questionnaire, after six months they were still above one (50\%), but with significant reduction $(\mathrm{p}<0.01)$, being observed that these values were achieved from the three months of follow-up. In the study by Wiles et al., ${ }^{26} 29 \%$ of patients showed HAQ II score above 1 (one) after two years of monitoring. Combe et al. ${ }^{27}$ reported that $27 \%$ of 191 patients had HAQ> 1 after a minimum of three years of follow-up, and $22 \%$ mainteined their scores after five years. The work of Young et al. ${ }^{28}$ had the same results after five years in $38 \%$. Possible explanations for the variations in the evolution of HAQ II score include different study designs and the influence of other variables, such as the effects of treatment and socioeconomic status.

Studies show that high HAQ II scores (early in the illness) should be warning signs, thus leading to more aggressive treatments to prevent the occurrence of deficiencies in the following years. ${ }^{29}$ Although most of the sample in this study (53.3\%) has more than five years of diagnosis, 93.3\% had moderate to severe initial HAQ II, demonstrating the impact of RA on a person's functional capacity, even using the traditional therapies (DMARDs).

Staples et al., ${ }^{30}$ evaluating a sample of 1801 RA patients treated with anti-TNF drugs and followed by a period of 60 months, found significant changes in the first six months of follow-up regarding the HRQL, which remained constant over the 60 months of treatment. The HAQ II score assessment was (baseline: 1.64, 6 months: 1.23 and 60 
months: 1.24) similar to the present study (baseline HAQ: 1.97 and 6 months: 1.23). This comparison can assist in research involving anti-TNF therapy and HRQL using the HAQ II that would not require many years of follow-up, six months being sufficient to evaluate the response to treatment. This result was also observed for the SF-36.

Regarding the SF-36, among the eight domains, six showed significant improvement (except overall state and mental health), after six months of follow-up. The small sample size may not have been enough to find statistical differences in these two domains, or the study duration was not sufficient for analysis considering its subjectivity.

Regarding the physical aspect and pain, this study had the highest results and were the domains that most influenced the patients in this work (the greatest complaints were with respect to pain and physical limitations to perform daily activities).

Regarding the association between anti-TNF and DMARD, some studies showed a more steep improvement in HRQL than the use of anti-TNF as monotherapy. ${ }^{31,30} \mathrm{In}$ this study, half of the patients received anti-TNF alone (monotherapy) and the other half received it in association. In comparing the two groups, there was no difference, probably due to the sample having been small for such a purpose, which suggests that further studies with larger samples must be conducted.

It was not possible to compare these results applying the SF-36 HRQL questionnaire with other scientific works, due to the scarcity of scientific papers using this instrument in patients with RA under specific anti-TNF therapy.

\section{Conclusion}

Thus, we conclude that the population, despite being on standard treatment (DMARDs) and presenting mostly over five years of diagnosis, showed significant improvements in HRQL and functional capacity in just three months of use of anti- TNF therapy, as assessed by the HAQ II and SF-36 instruments.

Despite having achieved no significant improvement in all SF-36 domains (except overall state and mental health), those that most impacted the patients before the study (pain and physical issues) were the ones with the best results.

\section{ACKNOWLEDGMENTS}

The team from the Infusion Center at the Oswaldo Cruz Teaching Hospital and the Clinics Hospital, as well as the Superintendency for Pharmaceutical Assistance, State Health Department of Pernambuco, Brazil.

\section{Resumo}

Qualidade de vida de portadores de artrite reumatoide em terapia biológica.

Objetivo: avaliar a qualidade de vida relacionada à saúde (QVRS) em portadores de artrite reumatoide (AR), antes e após o tratamento com terapia biológica.

Métodos: estudo longitudinal, realizado no período de novembro de 2010 a setembro de 2011, com aplicação dos instrumentos HAQ II (Health Assessment Questionnaire) e SF-36 (Medical Outcomes Short-From Health Survey). Foram realizados testes de Barlett, Anova, Friedman e teste-t pareado para múltiplos extratos.

Resultados: foram avaliados 30 pacientes, com idade média de 47,6 (DP: 12,25) anos e prevalência do gênero feminino (90\%). A média do escore do HAQ II antes do tratamento foi de 1,97 , com diminuição significativa de até 1,23 após seis meses de uso de terapia biológica $(\mathrm{p}<0,01)$. A maioria dos domínios do SF-36 apresentou significativa melhora após seis meses de tratamento $(p<0,01)$, destacando os aspectos sociais, dor, capacidade funcional, aspectos emocionais, vitalidade e aspectos físicos.

Conclusão: o uso de terapia biológica em pacientes com $\mathrm{AR}$, refratários aos tratamentos tradicionais, demonstrou ser uma importante estratégia farmacológica para a melhoria da QVRS.

Palavras-chave: artrite reumatoide, terapia biológica, qualidade de vida, reumatologia, doenças reumáticas.

\section{References}

1. Feldmann M, Brennan FM, Maini RN. Rheumatoid arthritis. Cell. 1996;85(3):307-10.

2. Alamanos Y, Drosos AA. Epidemiology of adult rheumatoid arthritis. Autoimmun Rev. 2005;4(3):130-6

3. Senna ER, De Barros AL, Silva EO, Costa IF, Pereira LV, Ciconelli RM, et al. Prevalence of rheumatic diseases in Brazil: a study using the COPCORD approach. J Rheumatol. 2004;31(3):594-7.

4. WHOQOL Group. The development of the World Health Organization quality of life assessment instrument (the WHOQOL). In: Orley J, Kuyken W, editors. Quality of life assessment: international perspectives. Heidelberg: Springer Verlag; 1994. p.41-60.

5. Ringash J, Bezjak A. A structured review of quality of life instruments for head and neck cancer patients Head Neck. 2001;23(3):201-3.

6. Mili F, Helmick CG, Moriarty DG. Health related quality of life among adults reporting arthritis: analysis of data from the Behavioral Risk Factor Surveillance System, US, 1996-99. J Rheumatol. 2003;30(1):160-6.

7. Marra CA, Woolcott JC, Kopec JA, Shojania K, Offer R, Brazier JE, et al. A comparison of generic, indirect utility measures (the HUI2, HUI3, SF-6D, and the EQ-5D) and disease-specific instruments (the RAQOL and the HAQ) in rheumatoid arthritis. Soc Sci Med. 2005;60(7):1571-82.

8. Arnett FC, Edworthy SM, Bloch DA, McShane DJ, Fries JF, Cooper NS. The American Rheumatism Association 1987 revised criteria for the classification of rheumatoid arthritis. Arthritis Rheum. 1988;31(3):315-24. 
9. Ministério da Saúde. Portaria SCTIE N. 710, de 27 de junho de 2013. Aprova o Protocolo Clinico e Diretrizes Terapêuticas da Artrite Reumatoide.

10. Ciconelli RM, Ferraz MB, Santos W, Meinão I, Quaresma MR. Tradução para língua portuguesa e validação do questionário genérico de avaliação de qualidade de vida SF-36. Rev Bras Reumatol. 1999;39(3):143-50.

11. Fries JF, Spitz P, Kraines G, Holman H. Measurement of patient outcome in arthritis. Arthritis Rheum. 1980;23(1):137-45.

12. Turesson C, Matesson EL. Vasculitis in rheumatoid arthritis. Curr Opin Rheumatol. 2009;21(1):35-40.

13. Markatseli TE, Alamanos Y, Saougou I, Voulgari PV, Drosos AA. Survival of TNF-alpha antagonists in rheumatoid arthritis: a long-term study. Clin Exp. Rheumatol. 2012;30(1)31-8.

14. Mota LMH, Laurindo IMM, Neto LLS. Avaliação prospectiva da qualidade de vida em uma coorte de pacientes com artrite reumatóide inicial. Rev Bras Reumatol. 2010;50(3):249-61.

15. Sokka T, Toloza S, Cutolo M. Women, men, and rheumatoid arthritis: analyses of disease activity, disease characteristics, and treatments in the QUESTRA study. Arthritis Res Ther. 2009;11(1):7.

16. Organização Mundial da Saúde (OMS). [citado 3 jun 2001]. Available at:

17. Silva AF, Matos NA, Lima AMS. Valor Diagnostico do Anticorpo Antipeptideo Citrulinado Ciclico na Artrite Reumatóide. Rev Bras Reumatol. 2006; 46(3):174-80.

18. Louzada-Junior P, Souza BDB, Toledo RA, Ciconelli RM. Analise descritiva das características demográficas e clinicas de pacientes com artrite reumatóide no Estado de São Paulo, Brasil. Rev Bras Reumatol. 2007;47(2):84-90

19. Mota LMH, Santos NLL, Burlingame R, Laurindo IMM. Comportamento distinto dos sorotipos do fator reumatóide em avaliação seriada de pacientes com artrite reumatóide inicial. Rev Bras Reumatol. 2009;49(3):223-35.

20. Travassos C, Viacava F, Pinheiro R, Brito A. Utilização dos serviços de saúde no Brasil: gênero, características familiares e condição social. Rev Panam Salud Publica. 2002;11(5-6):365-73.
21. Capilheira MF, Santos IS. Fatores individuais associados a utilização de consultas médicas por adultos. Rev Saúde Publica. 2006;40(3):436-43.

22. Barata RB. Gender and health inequalities among adolescents and adults in Brazil, 1998. Rev Panam de Salud Publica. 2007;21(5):320-7.

23. Carbacho MI, Dapueto JJ. Avaliação da capacidade funcional e da qualidade de vida de pacientes com artrite reumatóide. Rev Bras Reumatol. 2010;50(1):31-43.

24. Chermont GC. Resource utilization and the cost of rheumatoid arthritis in Brazil. Clin Exp Rheumatol. 2008;26(1):24-31.

25. Azevedo ABC, Ciconelli RM, Ferraz MB. Indirect costs of rheumatoid arthritis in Brazil. Value Health. 2008;11(5):869-77.

26. Wiles NJ, Dunn G, Barrett EM, Harrison BJ, Silman AJ, Symmons DP. One year follow up variables predict disability 5 years after presentation with inflammatory polyarthritis with greater accuracy than at baseline. J Rheumatol. 2000;27(10):2360-6.

27. Combe B, Cantagrel A, Goupille P, Bozonnat MC, Sibilia J, Eliaou JF. Predictive factors of 5-year health assessment questionnaire disability in early rheumatoid arthritis. J Rheumatol. 2003;30(11):2344-9.

28. Young A, Dixey J, Cox N, Davies P, Emery P, Gallivan S. How does functional disability in early rheumatoid arthritis (RA) affect patients and their lives? Results of 5 years of follow-up in 732 patients from the Early RA Study (ERAS). Rheumatology (Oxford). 2000;39(6):603-11.

29. Puolakka K, Kautiainen H, Mattonen T. Predictors of productivity loss in early rheumatoid arthritis: a year follow up study. Ann Rheum Dis. 2005; 64(1):130-3.

30. Staples MP, March L, Lassere M, Reid C, Buchbinder R. Health-related quality of life and continuation rate on first-line anti-tumour necrosis factor therapy among rheumatoid arthritis patients from the Australian Rheumatology Association Database. Rheumatology (Oxford). 2011;50(1):166-75.

31. Vibeke S, Jasvinder AS. Newer biological agents in rheumatoid arthritis: impact on health-related quality of life and productivity. Drugs. 2010; $70(2): 121-45$ 